\title{
Ecofeminist invitations in the works of Sindiwe Magona
}

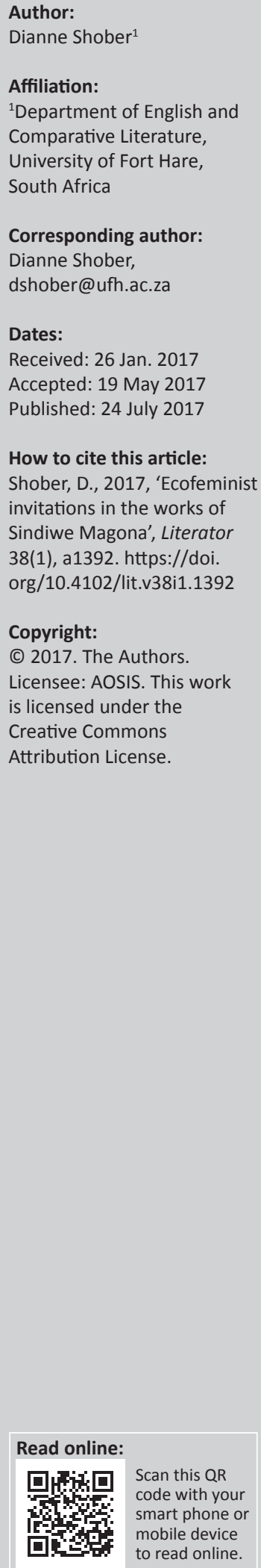

The global challenges of environmental devastation and gender-based injustice require a multifocal approach in appropriating effective solutions. While acknowledging the effectual endeavours initiated through the social and natural sciences to counteract these areas of degradation, this paper offers another field of potential mediation: ecofeminist literary criticism. Through its interrogation of selected works by the black South African writer, Sindiwe Magona, it seeks to reveal the value of literature as a tool to counteract destructive political and patriarchal rhetorical paradigms, which have served to oppress nature and women and, through ecofeminist discourse, mitigate lasting global change.

'n Uitnodiging tot ekofeministiese benaderings in die oeuvre van Sindiwe Magona. Die globale uitdagings van omgewingsverwoesting en geslagsgebaseerde onreg vereis 'n multifokale benadering ten einde doeltreffende oplossings te vind. Terwyl erkenning gegee word aan die effektiewe pogings geïnisieer deur die sosiale en natuurwetenskappe om hierdie gebiede van agteruitgang te bekamp, bied die artikel verdere potensiële bemiddeling deur middel van die ekofeministiese literêre kritiek. Deur geselekteerde werke van die swart SuidAfrikaanse skrywer Sindiwe Magona te ondersoek, beoog die artikel om die waarde van literatuur as 'n instrument teen die retoriese en vernietigende politieke en patriargale paradigmas wat die natuur en vroue onderdruk het, te openbaar. Dit beoog verder om deur middel van die ekofeministiese diskoers blywende globale verandering daar te stel.

\section{Introduction}

During the times of South Africa's greatest struggles, it was the probing literary expressions of our insightful and incendiary writers who unblinkered the eyes of the global community to the levels of oppression experienced by the majority of South Africans. Steve Biko's I Will Write What I Want, Nadine Gordimer's July's People, J.M. Coetzee's The Life and Times of Michael K and Sindiwe Magona's Living, Loving and Lying Awake at Night exposed to a global audience the sharpened edges of apartheid's injustices. As each of these writers drew aside the veil of silence and misinformation and revealed the identity rape of apartheid, readers were moved to potent political and social action.

But race was not the only area of repression. Women writers such as Olive Schreiner (1911), Bessie Head (1974), Lauretta Ngcobo (1990) and Zoe Wicomb (2000) highlighted the added layer of gender domination inflicted by a country of men, regardless of colour, who espoused strong patriarchal ideologies. These female authors' honest portrayals of gender-based inequality were designed to incite women to resist their diminished status.

Yet throughout the season of blossoming freedom literature, South African writers were also making literary efforts to record their environmental bond. The 1955 Freedom Charter proposed by the African National Congress stated 'that our people have been robbed of their birthright to land, liberty and place by a form of government founded on injustice and inequality'. The Charter's denouncement of South Africans' enforced removal from 'their birthright to land' was cited as their initial liberatory concern. Authors such as Peter Abrahams (1946), Alan Paton (1948) and A.C. Jordan (1980), and later J.M. Coetzee (1999b) and Zakes Mda (2000), embedded as they were within their social, political and cultural environment, also illuminated their characters' conscious link with their natural environment.

The achievement of democratic freedom further enhanced our authors' concerns for areas of liberation, not yet achieved, especially for women. In turn, this afforded renewed opportunities to explore the black South African's disenfranchisement with nature and culturally valued traditions. Over the decades, critics such as Olaniyan and Quayson (2007) have interrogated South African 
writers from a postcolonial, Marxist (Bartolovich \& Lazarus 2002), and African feminist lens (Arndt 2002), to mine the riches of their offerings, yet minimal attention has been given to scrutinise their works with a view to the authors' relationship with their natural environment. This is particularly noticeable in the glaring deficit of literary investigations under the lens of ecofeminist criticism. Black South African author Sindiwe Magona, who is renowned for addressing the HIV and AIDS crisis, championing black women's rights and advocating environmental security, explores the black woman's partnership with nature and, in her writings, attempts to reinvigorate concern for and interest in this syncretic alliance. An analysis of her selected works enables meaningful connections to the global concerns for sustainable development and the challenges of global change. It also opens a space of exploration to study through a more probing ecofeminist literary critique the black women's concern for and interaction with their environment.

\section{Ecofeminist criticism}

The literary critique afforded through ecofeminist criticism provides a sound grounding for the analysis of the selected South African literature that will be investigated in this paper. Given the centralised nature of both gender and environmental concerns, an ecofeminist paradigm provides an effective approach for uniting concerns regarding oppressions of women and nature. As this study utilises textual analysis, it is important to note that some ecofeminist theorists unite ecofeminist criticism with ecofeminist literary criticism (Boswell 2011; Buell 2005; Carr 2000; Gaard 2010; Gaard and Murphy 1998; Murphy 1995) seamlessly moulding both of these analytical frameworks.

Ecofeminist criticism draws a parallel between man's millennial attempts to subdue nature and women. Ecofeminism, according to seminal theorist Gaard (1994:22), attributes patriarchal notions of position and power as prime factors in the global environmental and gender oppression, citing the fact that patriarchy has tended to construct women, people of colour, animals and nature as the Other, thus diminishing their status and rights. Carlassare (2000:90) fuses misuse of the environment with the incumbent social and cultural challenges from which they are birthed. These hierarchal layers of oppression, enforced through various hegemonic structures, established rigid patterns of compliant behaviour resulting in systematic devastation of both the land and its people, an issue acute to the concerns of the ecofeminist.

A historical exploration of spiritual and ideological knowledge systems suggests a purposeful unification of women and nature, which in turn has led to the exploitation of both. González (2013:229) contends that historically gender oppression is synonymous with environmental abuses, and compounded by the expression of their similar passivity. Patriarchal religions espousing the worship of male deities advocated that men were to be awarded the ultimate position of authority over the earth, women and nature as their divine right. Additionally, men were instructed to protect and preserve humanity and the environment through the process of multiplication, involving both the seminal implantation of their seed in the wombs of women as well as the natural seeding of the soil, both of whom were required to be passive reservoirs.

Empirical, scientific explorations commencing in the 16th century determined that nature was meant to be treated like a piece of machinery that would accomplish a specific manmade purpose which dictated a view that allowed the abuse of nature to be an appropriate leap in industrialisation (Gaard \& Gruen 1993:236-237). Anthropology, a blossoming science in the 19th century, insisted that men were assigned the superior position because as the hunters of the society, a role they acquired through their masculine strength and ingenuity, they sustained the tribe by securing meat and protecting it from animal or human enemies. Women, on the other hand, defined in anthropological terms as the gatherers, were linked with the passive natural environment through their work with the soil and thus, allocated submissive, subordinate positions.

Marxists (Engels 1990:120) argue that capitalism and the laws supportive of property rights ensured that women were denied rights over their offspring by the men's authority to establish inheritance. Thus, men's view that women and children were an extension of their wealth reduce the class position of women and children and determine their exploitive economic value. Capitalist urgings further led to colonial desires of control and domination over lands and cultures under the guise of civilisation and humanist generosity. This provided Europeans with rich sources of cheap indigenous labour and limitless natural resources in other locales (Gaard \& Gruen 1993:239). According to Shiva (1988) from the systematic plundering of the soil through deforestation, mining, and monocultural crops, colonisation ensured the subjugation of women, indigenous people and nature.

It is the conglomeration of these flawed knowledge systems that lead 'ecofeminists [to] believe that the current global crises are the result of the mutually reinforcing ideologies of racism, sexism, classism, imperialism, naturism, and speciesism' (Gaard \& Gruen 1993:248). Karen Warren (2000:xiv-xv) in her important book Ecofeminist Philosophy adjures that environmental degradation is linked to the diminished status of each group that society has disregarded and disenfranchised and links this specifically to race, class, gender and age. As early as 1987, Warren (2000:17) was espousing that the women's movement must see women not only resisting patriarchal domination to ensure their own freedom, but also to protect and promote the preservation of the natural environment.

Ecofeminism has developed into two distinct forms, socialist and cultural ecofeminism, which still share the same goal of protecting and promoting women and nature, but choose separate models to appropriate these realities to create vital 
global change. Carlassare (2000:92) argues that socialist ecofeminists blame environmental abuses on male-oriented hierarchical modalities. As such the imperialist and capitalist forms of economic, social and political oppression are hegemonic forces inherent in the subjugation of both the environment and women. Socialist ecofeminists argue, however, that the environmental crises and gendered constructs are socially not spiritually produced (Merchant 1990:103).

Cultural ecofeminism, on the other hand, resists patriarchal limitations of women and rescribes them with affirmative characteristics, such as nurturance, compassion and emotional sensitivities. As such they elevate the status of women through their defined spiritual connection with nature and absorb spiritual and thus social significance through their association with ancient cultures that placed women in Godlike roles. Thus, they have denounced patriarchal religions that place men in the superior positions of authority and worship, arguing that these religions have served as oppressive forces to women and nature.

Both ecofeminist factions are change activists but seek different means to counteract environmental and gender injustices. Cultural ecofeminists as their name implies believe that transformation is possible through culturally inscribed motifs of language and spirituality, whereas social ecofeminists pursue change through empowering programmes and policies (Carlassare 2000:96).

Although there may not be one unified theory of ecofeminism and the proponents of the movement may centralise their advocacy programmes for global change from different theoretical and philosophical frameworks, there remain salient features of the movement that can propel gender equality forward and ensure global change which is sensitive to environmental concerns. As the selected articles by Sindiwe Magona may evidence, both groups are able to advocate for social change through valid and influential methods of engagement.

\section{Ecofeminist literary criticism}

Ecofeminist literary criticism, utilising the foundational tenets of ecofeminism, explores the interrelationship between the subjugation of women, nature and indigenous peoples as evidenced in literary texts. It provides a specialised theoretical lens to interrogate texts, providing a fresh look at how literary works express women's place in society and their relationship to nature. Additionally, it provides a space to explore cultural traditions and boundaries that may have subsumed gendered freedoms and identities while exploiting the environment and undermining global change. Mao-lin (2006:108) offers that ecofeminist literary criticism 'injects vitality and vigor into literary studies with its openness and interdisciplinarity' while assisting in the transformation of people's attitudes towards women and nature with the hope of achieving sustainable development. Li (2012:43), another Chinese scholar agrees, suggesting that ecofeminist literary criticism in its efforts to re-interrogate national and international texts, may help 'societies reestablish new cultural values to promote harmony between humans and nature and equality among all humans'. Both scholars readily agree that ecofeminist criticism is a vital investigative tool in analysing literature, especially those richly embedded in cultural paradigms.

Although ecofeminist literary criticism has been used to interrogate European, Asian, Native American and South American works as Gaard (2014:29) acknowledges in her text Ecocriticism, it is only now receiving burgeoning attention as an analytical tool to interrogate South African works. Analysis has centred on J.M. Coetzee's The Lives of Animals (1999) and Zakes Mda's The Heart of Redness (2000) and The Whale Caller (2006). Fewer articles have dedicated their ecofeminist scrutiny to black South African women writers although Boswell (2011) offered an insightful exploration of Ndlovu's poetry using an ecofeminist lens. Yet there is a surprising dearth of other similar literary investigations, and the works of black South African women writers allow rich exploration of the issues of injustice meted against women and nature, as this paper seeks to illustrate.

Ecofeminist literary criticism recognises the significance of language to construct social order and to stylise gender through expressions and terms that shape the position and condition of women and nature. Lionnet (2004:205) identifies the specific role of women writers as both language and literary specialists who use discourse as their revelatory and revolutionary weapon. Saikia (2014:77) argues that women writers are often instrumental agents of social change as they provide a literary voice for the silenced and sidelined Other. She insightfully contends that:

[a] woman can provide an insider's point of view both in terms of a marginalized class/caste and gender and hence, provide a better alternative than straightforward conservation which may, in fact, threaten the closure of the sources of fulfilling the needs of the tribals and cause an indigenous way of life that relied on and thus, possessed the knowledge and skill for conservation of biodiversity and sustainable development to disappear. (Saikia 2014:77-78)

This is especially true of black women writers who have endured the triple layers of race, class and gender oppression (Smith 1998:151). Claudia Tate (1983:xx) acknowledges the perceptive gaze of the black women writers who can effectively unravel the tangles of politics and patriarchy that maintain their diminished status. Numerous black women writers have united their social place to their physical space, in some cases decrying the decimated condition of their environment, in others embracing the land they call home. Sindiwe Magona, for instance, recounts in her short story titled 'Home' that her umbilical cord and her loved ones are buried in South Africa and thus she feels forever rooted to this soil. Explaining her return to South Africa after years of living and working in America, she (2006a:116) writes: 'But the bones in all these graves have called and I have returned'. 
Magona, who has won literary awards on three continents including President Zuma's prestigious Order of Ikhamanga, has spent the last two and half decades composing imaginative literary works within multiple literary genres, capturing the essence of what it has meant living in a social and political environment steeped in colonial and patriarchal suppression. Disconcerted with the various attempts by contemporary white writers to articulate the plight of the oppressed black woman living in the twilight of apartheid, she felt that the mantle of explication needed to shift to an insider, someone who from a grass roots level understood the layers of tyranny crushing a black woman. She sought to create 'a public, historical self, not only the self of the individual author, but also the self, as it were, of the race' (Gates 1987:180). Moreover, she longed to be a voice for those who lacked the education or the opportunity to be able to express their lives, those harassed domestic workers, struggling school girls, or overwhelmed single mothers, roles that she herself assumed as she transitioned from rural Transkei to an overcrowded Gugulethu township. Her determined efforts to escape poverty through education led her to an influential role in the United Nations as a translator on anti-apartheid radio. Yet every geographical and positional transition sharpened her awareness of the disparity and damage inflicted on women and the environment, which she expresses through her multifocal literary offerings. She declares herself a humanist and an environmentalist who:

has an abiding respect for all life ... Therefore, in my writing I do feminist issues, yes. But, once again, I hope this will not be to the exclusion of other life - human beings, plants, animals, in this or other worlds. (Koyana 2004:153)

She sees her role as a Nomabali, mother of stories, as an advocate of freedom for women and nature from gendered, economic and political repression.

\section{The ecofeminist voice in Magona's literary works}

Over the years, Magona's works have been examined through various literary theories, such as African feminism (Shober 2013), womanism (Gqola 2004; Koyana 2001), postcoloniality (Craps 2012), and Marxism (Daymond 1995). However, to date, the interrogatory lens has not shifted to explore her works within ecofeminist literary criticism. Yet, she herself embraces a praxis cognisant of the need for sustainable development and the concern for global change.

From 1992 to 2000, Magona wrote a series of short stories for the journal New Internationalist, a magazine which declares itself a champion for global justice. Magona's collection of articles lend themselves to ecofeminist literary criticism because of their narrative content and thematic nodes. These works further reveal her commitment to both feminist and environmentalist concerns and can be analysed within the paradigms of social and cultural ecofeminism, a framework that others are yet to employ. Through a careful textual analysis of her works, this paper seeks to illustrate how Magona expresses ecofeminist principles in an effort to inform and inspire her readers to engage in gender liberation and environmental security. The articles to be explored are 'The Possession' (1993), 'Mama Africa' (1998), 'The Scars of Umlungu' (1992) and 'The Beautiful Balding' (2000).

'The Possession' (1993) reflects strongly on socialist ecofeminist thought as it presents a series of disembodied voices taking possession of dignitaries speaking at an international conference entitled 'The Conference to Right the Wrongs of a World Woefully Out of Joint'. Although it is a global meeting of dignitaries presumably united to discuss and disseminate ideas on how to improve the fissures in fractured economies and crippling issues of social justice, the members appear to be headless suits who care little for the acute human and environmental concerns, lost instead in the malaise of a bureaucratic coma.

Yet into the midst of one's speaker's monotone murmurings is injected the voice of an old woman. Speaking through the lips of a pseudo-Asian delegate from 'Outer Manedristan', the elder charges:

Tell us we will be widows. Tell us we will raise our children all by ourselves. Tell us this when we are little girls. And then help us grow up strong and able to be widows who bring up children all alone. Arm us for this eventuality. Otherwise, what is the use of all this knowledge you gather, if it does not prepare the girlchild for her fate? (Magona 1993a:244)

Clearly, the clarion call here is to consider the girl children whose futures are being sold out to patriarchal structures whose agenda's minimise their value and reduce their agency. The lack of concern for their developmental needs is addressed by this ghostlike makulu in the hopes that the silenced voices of the marginalised and powerless youth and women will be heard. The deficiency in preparation coupled with the false promises of a secure future under the provision and protection of a husband is challenged by the speaker, who insists that young girls must be 'armed for the eventuality' of early widowhood and scant resources. Women, the makulu warns, are deceived into believing that men are their saviours, who will always be there to cover and care for them, yet this is rarely the case. These women, often denied an education awarded brothers, are left ignorant, unable to complete even simple financial transactions when early widowhood strikes.

Forced by their husbands to labour at home and care for their numerous children and extended families, women are economically disenfranchised when widowed, unable to secure bank loans from institutions that demand they know how to read and write. Makulu's admonition: 'Little girls, write... your... names. Learn! Learn to write your names'. The defining nature of language in creating identity and independence is offered in this simple challenge, especially as it addressed to the female who is often marginalised through enforced ignorance. The instruction 'Learn to write your names' is therefore about carving out an independent, autonomous space for women and girls in a world dominated by patriarchy. It is one that she echoes in another 
New Internationalist article titled 'Make Education Your Husband' (1993b:248). Here she writes: 'Akaboni (s/he is blind) say the Xhosa people of one who cannot read'. She recounts that her mother, limited as she was in her own education and position as a domestic, demanded that her children achieve an education stating: 'Education is a debt that each generation owes the next'.

Yet in her story 'The Possession' (1993a:244) the male members of the audience fail to listen. The speaker ignores the wraith-like interruption and drones on, oblivious to the moment and the message, completing his presentation, ironically entitled Abuse of human rights in some Third World countries. Equally, the next speaker, described as a 'smoothtongued' former president from the pseudo-nation of West Axum, is arrogantly obtuse. He commences his oration, only to be subsumed by the fragile voice of a tiny girl-child. Her appeal is plaintive, conjuring images of children dismembered by land mines or orphaned by war. Coming from such a little voice, her words are spear point in their sharpness:

Shut your big houses where death is manufactured. Seal the windows. Lock the doors of these terrible houses. Give the rich men who own them jobs in hospitals and bush clinics where they can see the results of their killing machines. Send them to work in the world's graveyards where they can read the sad tombstones of men, women and children killed in their games. Perhaps then other children will not lose their parents as I have, will not lose their homes. (1993a:244)

Her rebuke is directed at the capitalist war machine that generates conflicts to churn out wealth for the politicians and generals who command the carnage. Although there is no mention of the cost to the natural environment, the enormous price to human life is abundantly clear: 'the sad tombstones of men, women and children killed in their games'. In this apparition, education has become a weapon of destruction as men have used their intelligence to create 'killing machines', robbing children of their parents and their homes. Instead, the youngster advises 'lock the doors of these terrible houses' and open instead hospitals and clinics. Offer life, not death. Through the lisp of a girl-child, Magona supersedes the speech offered by a man whose war efforts are legendary, in order to remind the assembly of the human cost of war. Once again, Magona uses the voice of a disempowered female, a girl-child, to redirect the efforts of the wealthy elite, warning them that they may proceed and kill the planet and its people or use their power and positions to heal it.

The next voice taking possession of a corpulent speaker is that of a whimpering baby. Too young to have the capacity for language, it can only mewl in tones indicative of physical deprivation, yet its desperate cry breaks through the indifference of the audience. Although lacking the capacity for intelligible speech, the infant, through Magona's literary efforts, is given a platform to voice its objections to an assembly of overfed adults who, it appears, have turned a deaf ear to the impoverishment they have caused. Even years after the event, the listeners are haunted by the whimpering of this inconsolable infant.
The final voice is strong, clear, determined and direct, warning that the political and economic elite can no longer hide behind their false injunctions, their language of lies rejected. The disenfranchised have united, the intruder warns, and through their combined chorus of women, children, the impoverished and disabled the injustices will be overturned. The final ghostly orator commands the assembly to 'Listen', charging the delegates to hear the needs of those they pretend to represent. It scoffs: 'don't come and give us needs we didn't even know were there', suggesting that political sound bites offer platitudes without provisions, useless bromides without useable solutions.

The voices Magona interjects into the text, most of them female, are represented as grass roots activists who demand social justice and global change, not just an undoing of past mistakes, but a programme for improvement that will ensure safe and secure futures for women, children and their warravaged environments. Although Magona delivers a pulsing socialist message, she cautions that politicians may yet remain indifferent to the needs of their constituents and the environment. Still, she resonates a hopeful note that the impoverished will actively speak out and take possession of, through their social action, the meeting places of the political elite.

The second article under investigation, 'Mama Africa', was published in 1998 and is described in the spiritual terms of a parable. It portrays an elderly African prophetess calling to the masses to hear her words of wisdom. Cultural ecofeminists often utilise this persona to reinvigorate the position of women in their cultural world. This tale positions the African continent at its centre, lending to the notion of an Afrocentric motif that advises Africans to find African solutions to African problems. In Magona's story, pilgrims come from across the continent, seeking instruction, guidance and hope. A multitude of African languages are spoken, but unlike The Possession this is not babel, mindless, uncoordinated confusion, but the rich melody of diverse voices springing from the African land.

From the outset, the elderly seer is united to the earth. Magona describes her thus:

The web-cracks in the ancient mahogany face melded into the bark of the tree against which the Old Woman leant, her upper body upright as though it were but a branch or stump of that tree. Voluminous layers of heavy cotton skirt, ochre-coloured as the ground on which she sat, completely swathed her, hiding even her feet. Only the rich ivory of her teeth and her eyes, deep and wise, full of compassion, stood out. (1998:307)

Words such as 'mahogany', 'bark', 'branch', 'ochre-coloured' and 'ivory' all link the prophetess to the African soil. As she speaks, her soothing voice creates an image of the restorative nature of the natural African environment, unencumbered by colonialism or capitalism. But this story is not just the impartation of wisdom from the elderly to the innocent. It is a message of gendered transformation with the central role allocated to a young woman, Sizwe, whose name 
means 'we have been helped'. Sizwe represents the next generation of trailblazers who, having gained from the insights gleaned from the elders and the African environment, illustrate sensitivity to nature's needs and rhythms. Selected by her community and the ancestors, Sizwe has been awarded the sceptre of leadership to meet the prophetess, hear her counsel and return to deliver these instructions to her village.

At first insecure in her youthfulness and naiveté, she doubts her ability or selection, offering she is not yet appointed as one 'who sees'. Reassurred that both parentage and prophecy have set her apart, she presses on. At the collective council, Sizwe becomes invigorated by the human chorus of fellow souls uniting under the chant 'We are one! Sibanye!' But this unity is not limited to humans only. Through a sweeping poetic gesture, it includes all sentient life:

The ant, the tree, the flower and the bird

Life is a chain! We are one! Sibanye!

The fish, the duckling, the river and the wind

Life is a chain! It is a chain, for we are one! Sibanye! (1998:307)

Magona enjoins that for life on this planet to flourish all must respect, nurture and acknowledge that the links of life's chain are encircled by nature. Here again, Magona issues a warning, a break in the chain, bears a curse: 'damnation'. Failure to acknowledge and protect the needs of the natural environment will result in devastation for all who inhabit the earth.

Almost as if this instruction is too great to comprehend or the human needs are too pressing to ignore, the pilgrims cry out their petitions: 'hungry children'. To their pleas, Mama Africa directs them to the earth for their solution: 'Feed your children from its bounty'. But the assembly bemoans nature's decimation: 'The forests are bare'. They complain that the abuse of nature's resources has resulted in its inability to provide or sustain its human inhabitants. Yet, Mama Africa is undaunted with their complaints. 'Africa can feed her children', she resolutely declares.

But with a seer's ambiguity, she states: 'The children have hands. They are not only mouths. They have hands and feet and hearts and eyes and minds. Feed all these things. Feed by example, word and deed'. With these statements, she intimates that children must not only be fed physically, but intellectually and morally, learning from the example of their elders the culturally proscribed traditions. She reminds them that to protect one another, one must also protect the natural environment. Sustainable development is an interlinked chain between animate and inanimate beings.

Interestingly, it is the male voice that questions her statements, saying that she speaks in riddles and her words are confusing. The African tongue, initially enjoined as a unifying force to fuse the continent together, is now insufficient to conquer the gendered separation intimated by the man's question and complaint. Mama Africa offers a solution of unification, requiring men and women to respond together to the developmental needs of the African people and their continent, needs which demand the nurturance and cultivation of present and future generations. The prophetess' instruction suggests an empowerment through relationship and example, qualities and actions in cultural ecofeminist terms more often ascribed to women, and thus, it is little wonder that a man finds this directive too difficult to understand.

Mama Africa's pronouncements carry a strong ecofeminist tone as she makes a concerted link between humanity and the environment, citing that the life of a child is symbiotic with the life of a tree:

My children, she said. Celebrate life. Celebrate it and honour it. When a child is born, plant a tree to mark the event. Help both to grow strong and healthy. Let the child know the tree that is her life. Let her grow with it, loving it, nurturing it, protecting it even as she is loved, nurtured and protected. (1998:307)

Here the elderly sage is making a clear affiliation between the development of a child and the development of the environment. One cannot survive or thrive without the other. Nor is her directive a singular birth event. She encourages the assembly to: 'Plant another tree to mark each of the child's milestones'. But it isn't just to index important developmental passages. The sage indicates that by celebrating the life of the child, one perpetuates the safety and security of the planet, including its human and animal members. She declares by sustaining the environment through the planting trees:

that child will never be without firewood. Nor will the birds of the forest be bereft of homes. Thus not only will she cook her meals but she will also know the song of the bird, know the power in flight of its wing, the bright glint of its beady eye, the strength of its ferocious beak and the sharpness of its claw. (1998:307)

Mama Africa solidifies the African notion of the circle of life, the interconnectivity between the African, her continent, her environment and her life stating that she needs to be replenishing nature to be fully self-actualised.

Someone from the crowd again throws out a question. Although the respondent is not identified as male, the query hints of patriarchal prejudice: 'A woman? A woman needs to know of birds? But why so? She doesn't hunt'. Clearly the respondent has determined that the use of nature is only for consumption and conquering, exploits in the patriarchal tradition attributed to men, and not for instruction and appreciation of its magnificence and beauty.

The elderly prophetess responds in isiXhosa, an indigenous language, reminding those assembled that as Africans they should inhabit African traditions and understand the adage: 'umntu ngumntu ngabantu, a person is a person because of others'. It is a recognised statement highlighting the interconnectivity of the community, but the prophetess extends it to include an ecological union between humanity and their environment, suggesting that a person's commitment to sustainability requires them to embrace all 
living creatures: 'Umntu sisidalwa kwindalo, a person is a creature in creation'. Sibanye is extended to include both the social and natural environment. Cultural and human survival is dependent upon the nurturance of every living being housed on the earth. She explains:

All nature is linked. What happens to any part of that chain cannot but affect what happens to another. People and forests, rivers, seas and mountains, deserts and wetlands; beasts of the forest and those of the home; fish, fowl and flea; rain, sun, moon and stars... everything is one - connected, mutually dependent. (1998:307)

The prophetess then smoothly moves from a cultural ecofeminist paradigm to social ecofeminist ideologies, providing an almost seamless bridge between these two divergent and often opposed ecofeminist systems. In her efforts to stress the unity of creation, she removes hierarchical structures of ownership and rulership, declaring that every one is to be 'custodians of humane governance', advising that leaders need to hear the counsel and respond to the will of their people, and the people should play a participatory role in the governance of their countries.

When Sizwe returns to her village with the wisdom of Mama Africa, she envisions a village unified across gendered boundaries, with men and women working as one to nurture their children to adulthood. She does not foresee a community where women are assigned the role of mother and gardener, and men are apportioned the leadership role of hunter and shepherd. In Sizwe's new Africa, all human beings are essential, viable members actively engaged in ensuring society's social and environmental needs.

At the conclusion of the tale, Sizwe is awarded the title of 'mystic', 'Sheba's incarnate' and 'Mama Africa personified'. Magona clearly illustrates that the role of cultural and social headship may be assumed by a woman. Sizwe's gender does not negate her wisdom or ability, and patriarchal tradition should not prevent her from accomplishing her destined role of ensuring the survival of her people and her environment.

The Scars of Umlungu, published in New Internationalist in 1992, cites the connection between the African land decimated by colonial oppressors and the facial scars caused by the caustic cosmetics applied by eager Africans duped by the white beauty moguls. In the past, Magona suggests that Africans understood the sanctity of nature and knew it as a resource to be enjoyed by everybody. She writes: 'Thus my people knew how to flow with nature's rhythm, dance to its tune and harness its forces for their good. They knew about using and using up' (p. 230). According to Magona, only the colonisers thought that they could own and exploit nature, 'naming a star', claiming a territory, raping and fencing the land.

Magona exults the African tradition of respect for their environment and customs, nurturance of their people, as well as their lands. In contrast, she describes the plunder of the coloniser in violent terms: 'the newcomers cut up the land, cut it up until it bled, the stakes driven hard into its very heart, the barbed wire strangling it of breath'. She compares the destruction of the land with the repression of its people, indicating that they were 'lessened', 'reduced', prohibited by racial and political boundaries that appeared as irreversible as the decimation of the soil.

Through the presumed wisdom of the coloniser, fences were erected. The land was overcropped until only dust remained. Africans then needed white currency, 'buttons without holes', to purchase everything they were forced to need. Laws were passed to prevent the use of indigenous medicines and healing herbs were prohibited. By labelling their traditional medicine as 'backward' and 'heathen', Africans turned from their knowledge systems to the ways of their white, apparently civilised and educated, oppressors. Instead of putting ochre on their skin, the healing agents of the soil, women now applied skin lightening creams that burned their skin and left irreversible scars. By accepting the lies that white is better, African women, in particular, suffered the consequence of seeking to lighten the beauty of their African skin with painful potions in useless efforts to mimic their light-skinned oppressors.

Furthermore, the oppressor's discourse charged the African with ignorance, derailing their ways as 'things of the dark'. These epithets shamed the African into abandoning their centuries-old practices, compelling them to abandon the riches of the land, for the manufactured products of the coloniser. The title and description of these elixirs, 'Karroo Freckle and Complexion Cream' and 'Bu-tone Cream for Lovelier Complexion' promised that the smooth, beautiful skin of the African woman would be transformed into the pale, colourless façade of their oppressor. Having been humiliated by the accusations of ignorance, and propelled by the desires shared by woman around the globe, African woman surrendered their flawless image.

Moreover, the coloniser blamed any environmental inefficiencies to the African's mode of life, charging that 'the yawning dongas crisscrossing the land told Umlungu it was the women digging for their cosmetics that were to blame; it was our large herds of cattle, the women gathering firewood'. Instead, the colonisers offered, as they did with the cosmetics, to aid the uncivilised African by implementing new programmes, by removing them from their land, forcing them into the mines, gutting their lands in their drive for wealth. Magona declares:

my people watched their cattle getting thinner, their herds $\mathrm{dwindle}$, and the youth of the nation die in rock falls in the mines of the colourless ones, who made them dig for gold they would never own. (1992:230)

With strong socialist ecofeminist assertions, Magona argues that the coloniser robbed the land of its resources with the same veracity that they destroyed the smooth texture of the African woman's skin. She reasserts the importance of the harmony the African enjoyed with their natural environment, and reminds the reader that harming one maltreats the other. Furthermore, she charges the capitalist incursion as the source of the folly: 
Like the fences on the land the creams made umlungu plenty, plenty of buttons without holes... and killed our skin. Just like the fences had killed the land. Today thousands of us walk around with ugly, dark blotches on our faces, a disfigurement. The land has the scarring dongas and we have these hideous marks. (1992:230)

Although the African had no term to describe this disfigurement, the white perpetrators named it 'chloasma', certifying that the language of the dominant forces would not only declare their weapon but name its resultant destruction. Their discourse solidified their power over the land and its people.

Magona's short story formulates an effective interrogation of the double oppression suffered by the African woman using an ecofeminist paradigm, intimating that femininity and ecology are inexplicably linked. She suggests that the health of the land is irretrievably tied to the health of a woman and warns that surrendering an Afrocentric approach to physical and social sustainable development shatters the wellbeing of both.

'A Beautiful Balding' first appeared in New Internationalist in 2000. As the title suggests it presents an interesting comparison between the ever so slow incursion of hair loss for men with the gradual escalation of destruction to the African continent and its people through careless and indifferent management. The short story heralds the beginning of a group known as Genesis, which promotes the education and empowerment of young African woman. The pithy balding proverb offered by an elderly participant initially confuses the younger members uncertain how her words are to inspire their group. But one member's epiphany reveals the wisdom of the makulu's pronouncement, acknowledging the insightful juxtaposition that even as small changes can lead to massive losses, similarly miniscule social movements can result in monumental global changes.

In this tale, Magona unites the beginning of a new South Africa following the democratisation of 1994 with the biblical story of creation, and the fledgling Genesis group, destined to initiate the blossoming of the planet and its inhabitants. Similarly, Magona also heralds a new beginning for women; having escaped not only the subjugation of their colonial oppressors, it encourages them to escape the stifling confines of tribal patriarchy. She foretells a time of global change were a cross-pollination of children from African continents with African-American families would open not only minds but opportunities, enabling women to become heads of state and leaders in business, envisioning a time when '[g]irl children were more visible in all professions and trades'.

Magona also intimates that women are more attuned to the needs of both their social and natural environment, attesting that they were more inclined to answer 'the needs of their countries; turning deforestation around, turning children's malnutrition around', creating what she called 'a flowering of the continent!' This statement reinforces the social ecofeminist approach, recognising the significance of placing women in positions of governance as they will creatively and purposefully endeavour to address disparities plaguing human and environmental concerns.

In this short story, Magona paints a clear picture for the need of influential movements that would empower and release women to achieve their full potential, and, because of their strategic placement in world affairs, women leaders and professionals would ensure a flourishing of human and natural resources. Magona keenly links sustainable development with African women's liberation and indicates that programmes are necessary to see this come to fruition. It is a strong social ecofeminist manifesto which not only applauds the black woman for her ingenuity and zeal but her efforts for ecological development and global change.

Nor is it only in these short stories that Magona engages the social and natural environment of the African woman. In a table picture book entitled Mud Chic: Lifestyle and Inspiration from the Xhosa People of the Old Transkei (2006), Magona celebrates the simple beauty of rural life. Deliberately, she separates the concrete of capitalistic encrusted cities from the simple elegance of the natural environment, constructed as it is from the richness of the African soil. She writes:

The wonder of it. A hut made from the most basic ingredients. Earth and things from the earth, knit and woven together by the ingenuity of love and the inexhaustible imagination of the human spirit. (2006b:56)

In this passage, she clearly links the African and her home with the earth that has provided its 'ingredients', suggesting that through the generous bounty of the environment, the African has created not only her living quarters but her community. Magona (2006b) continues:

We hear of things such as electricity, tarred roads, water from the tap - but here, we live far away from those things. Perhaps, who knows, they may come to our village while we still live or so we hope. But for now we live today as we lived yesterday. We live from the kindness of God and the goodness of the land. (p. 126)

In this passage, Magona provides a spiritual connection between the natural resources available to sustain life with the creator who has extended his benevolent hand to release them into the care of his African people. It is an effect that she created when she described her rural roots in Gungululu, a village outside of Umtatha in which her early life was always intertwined with the complementary rhythms of her social and natural environment. Not so when she moved to the squashed confines of the Gugulethu townships. There she dealt with mud-filled lanes where faeces squished up between the toes, and crumbling shacks were tarred with newspaper affixed with rice glue. Yet, despite the desperateness of these airless, treeless communities, it was the vibrancy of the people swirling together in a surge to survive that enlivened her existence and posed her pen to write.

As these literary offerings attest, Magona is committed to be a change agent. Through her own determined rise from 
demarcated boundaries set by political and patriarchal configurations, she seeks to carve new pathways to freedom. In all her works, Magona calls to the thriving mass of African humanity to nurture all life, to actively engage in ensuring national, continental and global change, to resist complacency and react purposefully to ensure the sustainable development of South Africa's priceless natural and human resources.

\section{Conclusion}

The ecofeminist literary criticism utilised in this project interrogates the dynamic synergy of the social and natural environment, especially as they connect to issues of gender and socio-cultural inclusion. Using an Afrocentric lens ensures that the unique continental and ecological pressure plates are examined with the wisdom and insights of its home-grown experts, committed to finding African solutions to African challenges. Social and cultural ecofeminism, which Sindiwe Magona explicates in the works examined in this paper, affords a lens for discourse analysis that takes into account the subjugation of women and nature, while offering that the collaborative applications of sustainable development should apply to both.

This paper further acknowledges that African writers such as Sindiwe Magona have long been activists who reveal and revolutionise the state of their nation. Their literary voices have not only reflected the lives of the disenfranchised Other but offered recognition and release for those ensnared by gendered or political subjugations. In their concern for their people and their land, they have also noted the ecological devastation suffered from colonial oppression. Magona has used her creative energies and imaginations for the last three decades to challenge and subvert the hegemonic forces that have placed both women and their environment into inferior social, economic and political positions.

As a writer, Magona views her role as scribe for her people and the black African woman she represents who are beset by the triple oppression of race, class and gender. Throughout many of her works, she interweaves into her literary tapestry a stirring revelation of the uncanny connection between female oppression and ecological destruction. Moreover, she strives to charge her readers with the responsibility of engaging in recovering their own liberation while simultaneously securing ecological replenishment. Her ecofeminist renderings inform and inspire programmes of activation to ensure global change as well as share the richness of her African cultural traditions.

In conclusion, this paper recommends that scholars and activists on global change consider the efficacy of literature rendered by African authors such as Sindiwe Magona, as their critical and creative engagement oftentimes serve to promote environmental security and crush gender-based injustice. These writers' efforts, in conjunction with those in the social and natural sciences, can provide effective and long-lasting interventions to the current wave of global degradation.

\section{Acknowledgements Competing interests}

The author declares that she does not have any financial or personal relationships which may have inappropriately influenced her in writing this article.

\section{References}

Abraham, P., 1946, Mine Boy, Faber \& Faber, London.

Arndt, S., 2002, The dynamics of African feminism: Defining and classifying African feminist literatures, Africa World Press, Trenton, NJ.

Bartolovich, C. \& Lazarus, N., 2002, Marxism, modernity and postcolonial studies, Cambridge Press, Cambridge.

Boswell, B., 2011, 'Re-memory and an African ecofeminist poetic of healing in Malika Ndlovu's Poetry', Scrutiny2: Issues in English Studies in Southern Africa 16(2), 32-41. https://doi.org/10.1080/18125441.2011.631826

Buell, L., 2005, The future of environmental criticism: Environmental crisis and literary imagination, Blackwell, Malden, MA.

Carlassare, E., 2000, 'Socialist and cultural ecofeminism: Allies in resistance', Ethics \& the Environment 5(1), 89-101. https://doi.org/10.1016/S1085-6633(99)00025-X

Carr, G., 2000, New essays in ecofeminist literary criticism. Bucknell, UP, Lewisburg, PA.

Coetzee, J.M., 1999a, Disgrace, Martin Secker \& Warburg, London.

Coetzee, J.M., 1999b, The lives of animals, Princeton University Press, Princeton, NJ.

Craps, S., 2012, Postcolonial witnessing: Trauma out of bounds, Palgrave-MacMillan, London.

Daymond, M., 1995, 'Class in the discourses of Sindiwe Magona's autobiography and fiction', Journal of Southern African Studies 21(4), 561-572. https://doi. and fiction', Journal of Southern
org/10.1080/03057079508708465

Engels, F., 1990, The origin of the family, private property and the state, International Publishers, New York.

Gaard, G., 1994, 'Misunderstanding ecofeminism', Z Papers 3(1), 20-24.

Gaard, G., 2010, 'New directions for ecofeminism: Toward a more feminist ecocriticism', Interdisciplinary Studies in Literature and Environment 17(4), 643-665. https://doi.org/10.1093/isle/isq108

Gaard, G., 2014, Ecocriticism, Routledge, London.

Gaard, G. \& Gruen, L., 1993, 'Ecofeminism: Toward global justice and planetary health', Society and Nature 2, 1-35.

Gaard, G. \& Murphy, P., 1998, Ecofeminist literary criticism: Theory, interpretation, pedagogy, Urbana Illinois Press, Urbana.

Gates, H.L., 1987, Figures in black: Words, signs, and the racial self, Oxford University Press, New York.

González, M.C., 2013, 'Another Cassandra's cry: Mary Wollstonecraft's "universal benevolence" as ecofeminist praxis', Feminismo/s 22, 225-249.

Gqola, P., 2004, 'Forced to think: Innovation and womanist traditions in Sindiwe Magona's Wor(I)ds', in S. Koyana (ed.), Sindiwe Magona: The first decade, pp. 51-66, University of KwaZulu-Natal Press, Scottsville.

Head, B., 1974, The question of power, Heinemann, Johannesburg.

Jordan, A.C., 1980, Wrath of the ancestors, Lovedale Press, Alice.

Koyana, S., 2001, 'Womanism and nation-building in Sindiwe Magona's autobiographies', Agenda 50, 64-70.

Koyana, S., 2004, Sindiwe Magona: The first decade, University of KwaZulu-Natal Press, Scottsville.

Li, D., 2012, 'Ecofeminist literary criticism in Mainland China: A window into China's academic globalisation', Asian Women 28(4), 43.

Lionnet, F., 2004, 'Geographies of pain', in O. Nnaemeka (ed.), The politics of (m)othering: Womanhood, identity and resistance in African literature, pp. 205-227, Routledge, London.

Magona, S., 1992, 'The scars of Umlungu', New Internationalist, p. 230.

Magona, S., 1993a, 'The possession', New Internationalist, p. 244.

Magona, S., 1993b, 'Make education your husband', New Internationalist, p. 248.

Magona, S., 1998, 'Mama Africa', New Internationalist, p. 307.

Magona, S., 2000, 'A beautiful balding', New Internationalist, p. 326.

Magona, S., 2006a, 'Home', in S. Watson (ed.), A city imagined, pp. 107-116, Penguin, Rosebank.

Magona, S., 2006b, Mud Chic: Lifestyle and inspiration from the Xhosa People of the Old Transkei, Quivertree Publications, Cape Town.

Mao-lin, C., 2006, 'A discussion of ecofeminist literary criticism', Qilu Journal 4, 77-108.

Mda, Z., 2000, The heart of redness, Oxford University Press, Oxford.

Mda, Z., 2006, The whale caller, Picador, New York. 
Merchant, C., 1990, 'Ecofeminism and feminist theory', in I. Diamond \& G.F. Orenstein (eds.), Reweaving the world: The emergence of ecofeminism, pp. 100-105, Sierra Club Books, San Francisco, CA

Murphy, P., 1995, Literature, nature, other: Ecofeminist critiques, State University of New York Press, New York.

Ngcobo, L., 1990, And they didn't die, The Feminist Press, New York.

Olaniyan, T. \& Quayson, A., 2007, African literature: An anthology and criticism and theory, Wiley-Blackwell, Hoboken, NJ.

Paton, A., 1948, Cry, the beloved country, Charles Schribner \& Sons, New York.

Saikia, T., 2014, 'A matter of concern and a line of action: We matter too, an ecofeminist reading of some of Mahasweta Devi's fiction', Journal of Humanities and Socia Science 19(11), 75-78. https://doi.org/10.9790/0837-191167578

Schreiner, O., 1911, Woman and labour, Cape of Good Hope, De Aar.
Shiva, V., 1988, Staying alive: Women, ecology and development, Zed Books, London. Shober, D., 2013, Climbing higher: The literary life of Sindiwe Magona, David Philip Publisher, Cape Town.

Smith, B., 1998, 'Towards a black feminist criticism', in L. Goodman \& J. de Gay (eds.), The Routledge reader in gender and performance, pp. 149-155, Routledge, New York.

Tate, C., 1983, Black women writers at work, Continuum, New York.

The Freedom Charter, 1955, African National Congress, viewed 21 April 2015, from http://www.anc.org.za/show.php?id=72

Warren, K., 1987, 'Feminism and ecology: Making connections', Environmental Ethics 9(1), 3-20. https://doi.org/10.5840/enviroethics19879113

Warren, K., 2000, Ecofeminist philosophy: A western perspective on what it is and why it matters, Roman and Littlefield, New York.

Wicomb, Z., 2000, You can't get lost in Cape Town, The Feminist Press, New York. 